\title{
SENSITIVE KINETIC SPECTROPHOTOMETRIC METHOD FOR THE DETERMINATION OF DIPHENHYDRAMINE IN REAL SAMPLES
}

\author{
CÉSAR A. SOTO ${ }^{a}{ }^{*}$, RENATO A. SAAVEDRA ${ }^{b}$, CRISTIAN A. POZA $^{a}$, DAVID R. CONTRERAS ${ }^{a}$, \\ DIEGO P. OYARZÚN ${ }^{c}$ AND MARÍA I. TORAL ${ }^{d}$
}

\begin{abstract}
${ }^{a}$ Departamento de Química Analítica e Inorgánica, Facultad de Ciencias Químicas, Universidad de Concepción, Concepción, Chile.
${ }^{b}$ Departamento de Física, Facultad de Ciencias Física y Matemáticas, Universidad de Concepción, Concepción, Chile.

Centro de Nanociencias Aplicadas (CENAP), Facultad de Ciencias Exactas, Universidad Andrés Bello, Santiago, Chile.

${ }^{d}$ Laboratorio de Química Analítica, Facultad de Ciencias, Universidad de Chile, Santiago, Chile.
\end{abstract}

\begin{abstract}
Kinetic spectrophotometry methods have levels of accuracy and sensitivity which are comparable to those of other methods and have been used in the quantification of different pharmaceutical analytes in different matrices. This work describes an indirect kinetic spectrophotometric method for the determination of diphenhydramine by the alkaline oxidation with permanganate in pharmaceutical formulations (injection) and tap water spiked samples. Measurements of changes in absorbance at 610 $\mathrm{nm}$ were used as criterion of the reaction progress. The optimization of chemical variables of oxidation reaction was realized using experimental design by multivariate analysis. The optimized values were 20 min of reaction time, $\mathrm{KMnO}_{4} 1.00 \times 10^{-3} \mathrm{molL}^{-1}, \mathrm{Na}_{2} \mathrm{SO}_{4} 0.20 \mathrm{molL}^{-1}$ and $\mathrm{NaOH} 0.20 \mathrm{molL}^{-1}$. Under these conditions calibration curves were constructed. The detection limits obtained in pharmaceutical formulations (injection) and tap water spiked samples, were $9.65 \times 10^{-7}$ mol $\mathrm{L}^{-1}$ and $1.23 \times 10^{-}$ ${ }^{6} \mathrm{~mol} \mathrm{~L}^{-1}$, respectively. The method is simple and does not require expensive instruments or complicated extraction steps of the reaction product
\end{abstract}

Keywords: Kinetic, Spectrophotometric, Diphenhydramine.

\section{INTRODUCTION}

Diphenhydramine

hydrochloride,

2-(diphenylmethoxy)-N, $\mathrm{N}$-dimethylethanamine hydrochloride (DPH) (Figure 1), is a synthetic diphenylmethane which is symmetric, water-soluble and also ionizable at physiological $\mathrm{pH}$ [1]. This compound is used for common medical treatments such as hypnotic, antiparkinson, antiemetic, antitussive, hypersensitivity reactions and pruritus. However, when used as ingredient in cold preparations it provokes some undesired antimuscarinic and sedative effects. The monitoring of drugs is essential in pharmaceutical control and to avoid intoxications. In 1974, Caddy et al. [2] published two batch UV-vis spectrophotometric non kinetic assays for DPH indirect determination based on the analysis of some oxidation products of DPH. The oxidant reagents were $\mathrm{KMnO}_{4}$ and $\mathrm{K}_{2} \mathrm{Cr}_{2} \mathrm{O}_{7}$ in alkaline and acid media, respectively. Nevertheless, applications and analytical features were not informed. The British Pharmacopoeia [3] and the European Pharmacopoeia [4] both describe titrimetric methods for the determination of DPH, while the USP [5] describes a liquid chromatographic method [6]. Other reported methods in pharmaceutical formulations include spectrophotometry [713], chromatographic methods [14-20], FIA-Fluorometric [21-24], AAS [25-80], electroanalytical [28, 29] and capillary electrophoresis [30-33]. Furthermore, DPH has been measured in biological samples (human and animals) using spectrophotometry [8, 34] and different chromatographic methods [35-38]. Some of the reported methods have limitations such as time-consuming procedures, interference from substances and/or relatively high cost of instrumentation. Kinetic spectrophotometry methods have comparable levels of accuracy and sensitivity to the methods above mentioned and have been used in the quantification of different pharmaceutical analytes in different matrices [39-43]. In these methods, the absorbance variation in the time is measured under nonequilibrium conditions. This work describes the utility of permanganate (MnO4-) oxidant reagent (alkaline medium) for indirect kinetic spectrophotometric determination of DPH in pharmaceutical formulations (injection) and tap water spiked samples. The analyte alkaline oxidation produce the reduction of permanganate to manganate ( $\mathrm{MnO} 42-)$ that was monitorized at $610 \mathrm{~nm}$. Furthermore, the optimization of chemical dependent variables of oxidation reaction were studied by using experimental design via multivariate analysis.<smiles>CN(C)CCOC(c1ccccc1)c1ccccc1</smiles>

Figure 1. 2-(diphenylmethoxy)- $N, N$-dimethylethanamine hydrochloride, DPH.

\section{MATERIALS AND METHODS}

\subsection{Instruments.}

A Perkin Elmer Lambda 35 double beam spectrophotometer with matched quartz cells $(10 \mathrm{~mm})$ was used for spectral measurements in the range between 190 and $800 \mathrm{~nm}$ against blank. The spectral data were processed by Perkin Elmer UV Win Lab Data Processor and Viewer 1.00. Analytical balance AS 60/220/C/2 $( \pm 0.01 \mathrm{mg})$ and $\mathrm{pH}$-meter Hanna were used.

\subsection{Reagents.}

Stock solution of diphenhydramine hydrochloride $\left(1.1 \times 10^{-3} \mathrm{~mol} \mathrm{~L}^{-1}\right)$ was prepared by dissolving $0.016 \mathrm{~g}$ of it in deionized water and diluting to the mark of $50 \mathrm{ml}$ volumetric flask. Working standards were freshly prepared by diluting the stock solution with deionized water to obtain appropriate concentrations. Aqueous solutions of $\mathrm{NaOH} 1.00 \mathrm{~mol} \mathrm{~L}^{-1}, \mathrm{KMnO}_{4} 9.80 \times 10^{-2} \mathrm{~mol} \mathrm{~L}^{-1}$, and $\mathrm{Na}_{2} \mathrm{SO}_{4} 2.00 \mathrm{~mol} \mathrm{~L}^{-1}$ were prepared from Merck reagents.

\subsection{Procedures.}

\subsubsection{Kinetic Procedure.}

Adequate aliquots of solutions of, DPH (stock), $\mathrm{KMnO}_{4} 9.80 \times 10^{-2} \mathrm{~mol} \mathrm{~L}^{-1}$, $\mathrm{NaOH} 1.00 \mathrm{molL}^{-1}$, and $\mathrm{Na}_{2} \mathrm{SO}_{4} 2.00 \mathrm{~mol} \mathrm{~L}^{-1}$, were used in the preparation of the assays in $5.00 \mathrm{ml}$ amber standard flasks. The absorbance of solutions was measured at $610 \mathrm{~nm}\left(A_{610}\right)$ after $20 \mathrm{~min}$. External calibration using prepared standards of DPH and blank in the range $2.00 \times 10^{-6}$ to $4.00 \times 10^{-5} \mathrm{~mol} \mathrm{~L}^{-1}$ was carried out and the regression equation was attained. For the determination of the order of reaction, $\log \mathrm{v} v / \mathrm{s} \log [\mathrm{DPH}]$ was plotted.

\subsubsection{Optimization by response surface methodology.}

The central composite circumscribed (CCC) model [44] was used to determine the optimal experimental conditions and establish the interactions between the independient variables (Concentrations of $\mathrm{NaOH}, \mathrm{Na}_{2} \mathrm{SO}_{4}, \mathrm{KMnO}_{4}$ and reaction time) for the maximization of the absorvance at $610 \mathrm{~nm}$ (dependent variable, $\left.A_{610}\right)$. For this purpose, twenty seven experiments were carried out to find the optimal conditions for achieving the complete of DPH oxidation $\left(2.00 \times 10^{-5}\right.$ $\mathrm{molL}^{-1}$ ). The values of the variables are showed on Table 1 . The model was statistically validated using analysis of variance (ANOVA) with a 95\% confidence level. The data analysis was performed using the statistical software Modde 7.0 (Umetrics).

\subsubsection{Calibration curve in Proposed Samples.}

Tap Water Spiked Samples: The calibration curve in tap water was prepared by following the procedure of section 2.3.1, except it was diluted up to the mark with treated tap water according to the next section (2.3.4). 
Pharmaceutical Formulations: The calibration curve was prepared with adequate volumes accurately measured of Alergyl ${ }^{\mathrm{TM}}$ injectable $\left(10 \mathrm{mg} \mathrm{mL}^{-1}\right)$ and were quantitatively transferred into a $5.00 \mathrm{ml}$ standard flask, and the it following the procedure of the section 2,3.1, except it was diluted up to the mark with distilled water (commercial injection ampules).

\subsubsection{Procedure for the proposed samples}

Tap Water Spiked Samples: The samples analyzed $(500 \mathrm{~mL})$ were gathered from taps located in laboratorie and were collected in polyethylene bottles without adding any preservative agent and analyzed within $5 \mathrm{~h}$. Then, the samples were boiled $(20 \mathrm{~min})$ and filtered $(0.22 \mu \mathrm{m})$. Aliquots of the tap water were spiked with known concentrations of DPH. Then, samples were prepared according to the procedure described above (Section 2.3.1).

Pharmaceutical Formulations: Adequate aliquots of ten commercial ampoules (Alergyl ${ }^{\mathrm{TM}}$ ) of DPH hydrochloride injections $\left(10 \mathrm{mg} \mathrm{mL}^{-1}\right)$, were accurately measured. Then, samples were prepared according to the procedure described above (Section 2.3.1)

\section{RESULTS AND DISCUSSIONS}

Manganate $\left(\mathrm{MnO}_{4}{ }^{2-}\right)$ is produced in the reaction of $\mathrm{DPH}$ with $\mathrm{KMnO}_{4}$ under alkaline conditions, which is evidenced by the proportional increase of absorption (450 and $610 \mathrm{~nm}$ ) with DPH concentration. The univariate method was used in the studies of the experimental variables effect (Reaction time ( $t$ ), concentrations of $\mathrm{NaOH}, \mathrm{KMnO}_{4}$, and $\mathrm{Na}_{2} \mathrm{SO}_{4}$ ) on the reaction behavior. Then, only the variables involved in the formation of reduction product of $\mathrm{KMnO}_{4}$ were optimized and absorbance measurements at $610 \mathrm{~nm}\left(A_{610}\right)$ using DPH $2.00 \times 10^{-5}$ mol L ${ }^{-1}$ were carried out.

\subsection{Study of the effect of experimental variables.}

The effect of $\mathrm{KMnO}_{4}$ concentration on the reaction over the range $5.00 \times 10^{-4}$ $1.20 \times 10^{-3} \mathrm{~mol} \mathrm{~L}^{-1}$ was studied (Figure 2). The results show a proportional dependence between the increase of reaction rate and the augment of oxidant concentration. As seen in Figure 2, the signal has a large increase up to concentrations close to $9.00 \times 10^{-4} \mathrm{~mol} \mathrm{~L}^{-1}$, however, at higher concentrations a decline in the increase of the signal is observed $(0.02$ [au]). However, this does not affect the reaction rate which depends on substrate concentration, thus $9.00 \times 10^{-4} \mathrm{~mol} \mathrm{~L}^{-1}$ was initially selected. The results of the study of $\mathrm{NaOH}$ concentration effects showed the influence of the alkalinity of the medium in the oxidation reaction. $\mathrm{NaOH}$ concentrations between 0 and $0.60 \mathrm{~mol} \mathrm{~L}^{-1}$ were used (Figure 3). The absorbance variations for each $\mathrm{NaOH}$ concentration value decreased from $0.30 \mathrm{molL}^{-1}$. The value of $0.34 \mathrm{~mol} \mathrm{~L}^{-1}$ was selected. The effects of $\mathrm{Na}_{2} \mathrm{SO}_{4}$ concentration (ionic strength) on the reaction rate revealed that the variation of this compound did not significantly affect the $\mathrm{MnO}_{4}{ }^{2-}$ formation, showing a slow absorbance increase, corresponding to 0.05 [au] from 0 to 0.60 mol L${ }^{-1}$ (Figure 4). To maintain constant ionic strength, $0.20 \mathrm{~mol} \mathrm{~L}^{-1}$ was used. Absorbance measurements were performed every $10 \mathrm{~min}$ in an interval from 0 to $60 \mathrm{~min}$, in order to assess reaction time effects (Figure 5). The absorbance values increased proportionally up to $30 \mathrm{~min}$. For longer times the difference in absorbance was negligible. Based on this, 20 min was selected as reaction time $(t)$.

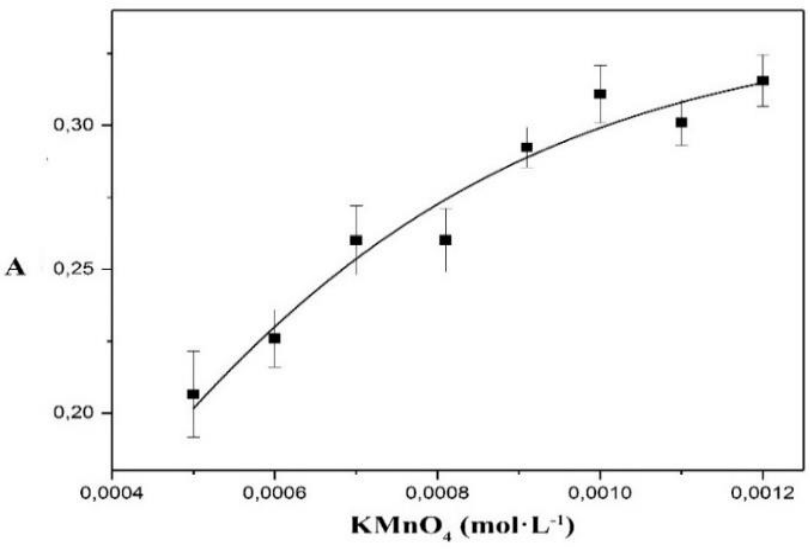

Figure 2. Effect of $\mathrm{KMnO}_{4}$ concentration $\left(5.00 \times 10^{-4}-1.20 \times 10^{-3} \mathrm{~mol} \mathrm{~L}^{-1}\right)$ on the $\mathrm{DPH}-\mathrm{KMnO}_{4}$ system, with DPH $4.00 \times 10^{-5} \mathrm{~mol} \mathrm{~L}^{-1}, \mathrm{Na}_{2} \mathrm{SO}_{4} 0.20 \mathrm{~mol} \mathrm{~L}^{-1}$, $\mathrm{NaOH} 0.34 \mathrm{~mol} \mathrm{~L}^{-1}, t=20 \mathrm{~min}$, and monitoring $A_{610}$.

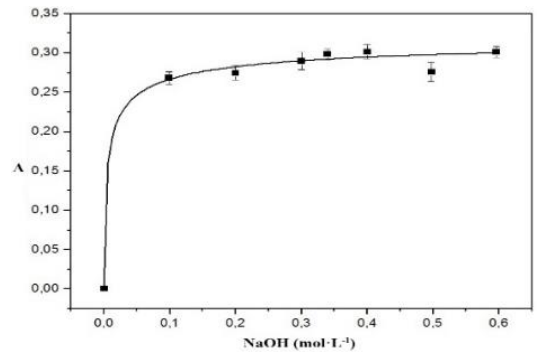

Figure 3. Effect $\mathrm{NaOH}$ concentration $\left(0-0.60 \mathrm{~mol} \mathrm{~L}^{-1}\right)$ on the $\mathrm{DPH}-\mathrm{KMnO}_{4}$ system, with DPH $4.00 \times 10^{-5} \mathrm{molL}^{-1}, \mathrm{KMnO}_{4} 9.00 \times 10^{-4} \mathrm{molL}^{-1}, \mathrm{Na}_{2} \mathrm{SO}_{4} 0.20$ $\mathrm{molL}^{-1,} t=20 \mathrm{~min}$ and monitoring $A_{610}$.

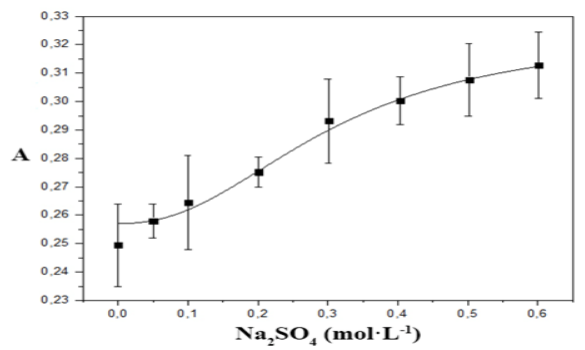

Figure 4. Effect of $\mathrm{Na}_{2} \mathrm{SO}_{4}$ concentration $\left(0-0.60 \mathrm{~mol} \mathrm{~L}^{-1}\right)$ on the DPH$\mathrm{KMnO}_{4}$ system, with $\mathrm{DPH} 4.00 \times 10^{-5} \mathrm{molL}^{-1}, \mathrm{NaOH} 0.34 \mathrm{molL}^{-1}, \mathrm{KMnO}_{4}$ $9.00 \times 10^{-4} \mathrm{molL}^{-1}$, and $t=20 \mathrm{~min}$ and monitoring $A_{610}$.

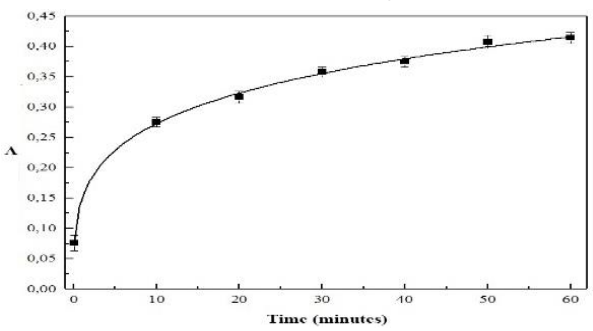

Figure 5. Effect of $t(0-60 \mathrm{~min})$ on the $\mathrm{DPH}-\mathrm{KMnO}_{4}$ system, at $\mathrm{NaOH} 0.34$ molL ${ }^{-1}$, DPH $4.00 \times 10^{-5} \mathrm{molL}^{-1}, \mathrm{KMnO}_{4} 9.00 \times 10^{-4} \mathrm{molL}^{-1}, \mathrm{Na}_{2} \mathrm{SO}_{4} 0.20 \mathrm{molL}^{-1}$ and monitoring $A_{610}$.

\subsection{Variables Optimization.}

The optimization of the reaction variables using response surface methodology allows us to find the optimal values in a defined range with a minimum set of experiments. The procedure permits getting a polynomial describing the relevance and interactions between the variables obtaining a graphical 3-D representation or surface plot [45]. Table 1 shows the set of experiments performed defined by the CCC model. Experiments numbers 20 and 22 were discarded since the concentration values of the $\mathrm{KMnO}_{4}$ and $\mathrm{Na}_{2} \mathrm{SO}_{4}$ (coding +2) generate a scattering effect of the light beam producing wrong absorbance values. The second and third columns depict the initial values of the variables and, in parenthesis, the codified values. Experimental and calculated values obtained for each reaction are shown in the two last columns. A response polynomial was obtained from multiple lineal regression (MLR). This polynomial describing the relevance of variables and their interaction in the whole process (Eq. 1). The results presented in the Table 1 show great concordance between theoretical and experimental absorbances $\left(\mathrm{Y}_{\exp }\right.$ and $\left.\mathrm{Y}_{\text {calc }}\right)$. The $t$ and $\mathrm{KMnO}_{4}$ concentration, shows the highest effect on the DPH oxidation. An antagonic interaction between variables $\mathrm{NaOH}$ concentration and $t$ is showed by the polynomial Eq.1. A plot of the response surface for the main variables, $t$ and $\mathrm{KMnO}_{4}$ concentration is shown in Fig. 6, where maximum $A_{610}$ is reached at high values of these variables. The optimal values of model were, $t=21 \mathrm{~min}, \mathrm{KMnO}_{4}$ concentration $=1.00 \times 10^{-3} \mathrm{~mol}$ $\mathrm{L}^{-1}$. In contrast, the $\mathrm{NaOH}$ and $\mathrm{Na}_{2} \mathrm{SO}_{4}$ concentrations have a lower effect, for which the model predicts using concentrations of $0.20 \mathrm{~mol} \mathrm{~L}^{-1}$ for each one these variables. The experimental verification of the value delivered by the model was made, obtaining the values predicted (Table 2). Finally the model was adjusted at $\mathrm{KMnO}_{4}$ concentration $=1.00 \times 10^{-3} \mathrm{~mol} \mathrm{~L}^{-1}$ and $t=20 \mathrm{~min}$. 
Eq.1. $A_{610}=(0.32 \pm 0.01)+(0.0052 \pm 0.0045) \mathrm{NaOH}+(0.0052 \pm 0.0054) \mathrm{Na}_{2} \mathrm{SO}_{4}+(0.011 \pm 0.0051) \mathrm{KMnO}_{4}+(0.017 \pm 0.0046) t-(0.010 \pm 0.0048) \mathrm{NaOH}+$ $(0.014 \pm 0.0062) \mathrm{Na}_{2} \mathrm{SO}_{4}{ }^{2}-(0.024 \pm 0.0048) t^{2}-(0.011 \pm 0.0056) \mathrm{NaOH} \cdot t$

Table 1. CCC design for oxidation DPH. Response factor was defined $A_{610} \mathrm{~nm}$ for DPH concentration $2.00 \times 10^{-5} \mathrm{~mol} \mathrm{~L}^{-1}$. In parenthesis the codified values.

\begin{tabular}{|c|c|c|c|c|c|c|}
\hline Run & $\mathrm{NaOH}\left[\mathrm{molL}^{-1}\right]$ & $\mathrm{Na}_{2} \mathrm{SO}_{4}\left[\mathrm{molL}^{-1}\right]$ & $\begin{array}{l}\mathrm{KMnO}_{4} \\
{\left[\mathrm{molL}^{-1}\right]}\end{array}$ & $\begin{array}{c}t \\
{[\mathrm{~min}]}\end{array}$ & $\begin{array}{c}\mathbf{Y}_{\exp } \\
{\left[A_{610}\right]}\end{array}$ & $\begin{array}{c}\mathbf{Y}_{\text {calc }} \\
{\left[A_{610}\right]}\end{array}$ \\
\hline $\mathrm{N} 1$ & $0.2(-1)$ & $0.3(-1)$ & $8.0 \times 10-4(-1)$ & $10(-1)$ & 0.2473 & 0.2311 \\
\hline $\mathrm{N} 2$ & $0.4(+1)$ & $0.3(-1)$ & $8.0 \times 10-4(-1)$ & $10(-1)$ & 0.2590 & 0.2805 \\
\hline $\mathrm{N} 3$ & $0.2(-1)$ & $0.5(+1)$ & $8.0 \times 10-4(-1)$ & $10(-1)$ & 0.2538 & 0.2584 \\
\hline $\mathrm{N} 4$ & $0.4(+1)$ & $0.5(+1)$ & $8.0 \times 10-4(-1)$ & $10(-1)$ & 0.3225 & 0.3078 \\
\hline N5 & $0.2(-1)$ & $0.3(-1)$ & $1.0 \times 10-3(+1)$ & $10(-1)$ & 0.2539 & 0.2536 \\
\hline N6 & $0.4(+1)$ & $0.3(-1)$ & $1.0 \times 10-3(+1)$ & $10(-1)$ & 0.2802 & 0.2703 \\
\hline $\mathrm{N} 7$ & $0.2(-1)$ & $0.5(+1)$ & $1.0 \times 10-3(+1)$ & $10(-1)$ & 0.2755 & 0.2809 \\
\hline N8 & $0.4(+1)$ & $0.5(+1)$ & $1.0 \times 10-3(+1)$ & $10(-1)$ & 0.3013 & 0.2976 \\
\hline N9 & $0.2(-1)$ & $0.3(-1)$ & $8.0 \times 10-4(-1)$ & $20(+1)$ & 0.2575 & 0.2872 \\
\hline $\mathrm{N} 10$ & $0.4(+1)$ & $0.3(-1)$ & $8.0 \times 10-4(-1)$ & $20(+1)$ & 0.3110 & 0.2914 \\
\hline N11 & $0.2(-1)$ & $0.5(+1)$ & $8.0 \times 10-4(-1)$ & $20(+1)$ & 0.2934 & 0.2809 \\
\hline N12 & $0.4(+1)$ & $0.5(+1)$ & $8.0 \times 10-4(-1)$ & $20(+1)$ & 0.2669 & 0.2851 \\
\hline $\mathrm{N} 13$ & $0.2(-1)$ & $0.3(-1)$ & $1.0 \times 10-3(+1)$ & $20(+1)$ & 0.3334 & 0.3428 \\
\hline N14 & $0.4(+1)$ & $0.3(-1)$ & $1.0 \times 10-3(+1)$ & $20(+1)$ & 0.3180 & 0.3143 \\
\hline N15 & $0.2(-1)$ & $0.5(+1)$ & $1.0 \times 10-3(+1)$ & $20(+1)$ & 0.3490 & 0.3365 \\
\hline N16 & $0.4(+1)$ & $0.5(+1)$ & $1.0 \times 10-3(+1)$ & $20(+1)$ & 0.2891 & 0.3080 \\
\hline N17 & $0.1(-2)$ & $0.4(0)$ & $9.0 \times 10-4(0)$ & $15(0)$ & 0.2659 & 0.2639 \\
\hline N18 & $0.5(+2)$ & $0.4(0)$ & $9.0 \times 10-4(0)$ & $15(0)$ & 0.2863 & 0.2848 \\
\hline N19 & $0.3(0)$ & $0.2(-2)$ & $9.0 \times 10-4(0)$ & $15(0)$ & 0.3700 & 0.3664 \\
\hline N20 & $0.3(0)$ & $0.6(+2)$ & $9.0 \times 10-4(0)$ & $15(0)$ & 0.3020 & 0.3413 \\
\hline $\mathrm{N} 21$ & $0.3(0)$ & $0.4(0)$ & $7.0 \times 10-4(-2)$ & $15(0)$ & 0.2689 & 0.2653 \\
\hline $\mathrm{N} 22$ & $0.3(0)$ & $0.4(0)$ & $1.1 \times 10-3(+2)$ & $15(0)$ & 0.2659 & 0.2917 \\
\hline $\mathrm{N} 23$ & $0.3(0)$ & $0.4(0)$ & $9.0 \times 10-4(0)$ & $5(-2)$ & 0.1755 & 0.1840 \\
\hline $\mathrm{N} 24$ & $0.3(0)$ & $0.4(0)$ & $9.0 \times 10-4(0)$ & $25(+2)$ & 0.2627 & 0.2505 \\
\hline $\mathrm{N} 25$ & $0.3(0)$ & $0.4(0)$ & $9.0 \times 10-4(0)$ & $15(0)$ & 0.3148 & 0.3198 \\
\hline $\mathrm{N} 26$ & $0.3(0)$ & $0.4(0)$ & $9.0 \times 10-4(0)$ & $15(0)$ & 0.3295 & 0.3198 \\
\hline $\mathrm{N} 27$ & $0.3(0)$ & $0.4(0)$ & $9.0 \times 10-4(0)$ & $15(0)$ & 0.3150 & 0.3198 \\
\hline
\end{tabular}

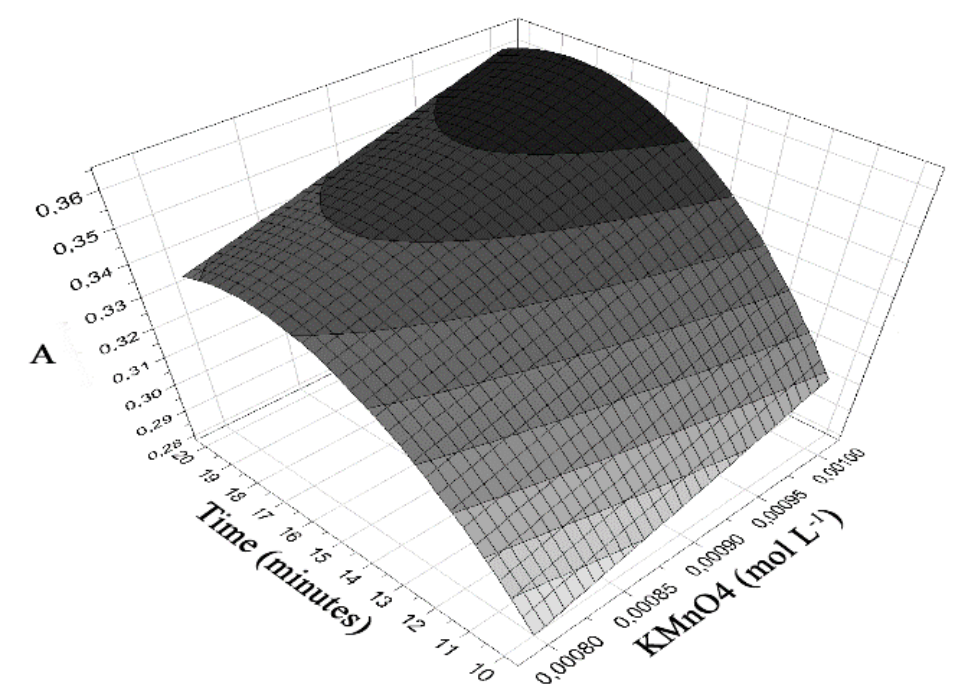

Figure 6. Response surface obtained by response polinomyal plot of $\mathrm{KMnO}_{4}$ concentration and $t$ as independent variables. The $\mathrm{NaOH}$ and $\mathrm{Na}_{2} \mathrm{SO}_{4}$ concentrations were constant at $0.20 \mathrm{~mol} \mathrm{~L}^{-1}$.

\begin{tabular}{|c|c|c|c|c|c|}
\hline Value & $\begin{array}{c}\mathbf{N a O H} \\
{\left[\mathbf{m o l L}^{-1}\right]}\end{array}$ & $\begin{array}{c}\mathbf{N a}_{2} \mathbf{S O}_{4} \\
{\left[\mathbf{m o l L}^{-1}\right]}\end{array}$ & $\begin{array}{c}\text { KMnO }_{4} \\
{\left[\mathbf{m o l L}^{-1}\right]}\end{array}$ & $\begin{array}{c}\text { A } \\
{[\mathbf{m i n}]}\end{array}$ \\
\hline Foretold & 0.196 & 0.200 & $1.08 \times 10^{-3}$ & 21.3 & 0.3938 \\
\hline Obtained & 0.200 & 0.200 & $1.00 \times 10^{-3}$ & 21.0 \\
\hline Used & 0.200 & 0.200 & $1.00 \times 10^{-3}$ & 0.3882 \\
\hline
\end{tabular}




\subsection{Stoichiometry Determination.}

The stoichiometric relation was determined using the logarithmic method [46], optimized experimental conditions and monitoring at $610 \mathrm{~nm}$. Plots of $\log A \mathrm{v} / \mathrm{s}$ $\log [\mathrm{DPH}]$ at constant $\mathrm{KMnO}_{4}$ concentration and $\log A \mathrm{v} / \mathrm{s} \log \left[\mathrm{KMnO}_{4}\right]$ at constant DPH concentration, give straight lines with slopes of 1.068 and 1.164, respectively. Thus, the molar ratio of the reaction is $1.068: 1.164 \approx 1: 1$.

\subsection{Kinetic of the Reaction.}

Considering pseudo-first order conditions $\left(\left[\mathrm{KMnO}_{4}\right]>[\mathrm{DPH}]\right)$ and the optimized variables, the kinetic behavior of reaction can be represented by the equation $\mathrm{v}=\mathrm{k}^{\prime}[\mathrm{DPH}]^{\mathrm{n}}$. From the plot of $\log \mathrm{v} v / \mathrm{s} \log [\mathrm{DPH}]$, the order of reaction $(n)$ and rate constant $\left(\mathrm{k}^{\prime}\right)$ were obtained, the values were $0.906(\approx 1)$ and 13.33 $\mathrm{s}^{-1}$, respectively.

\subsection{Evaluation of the Kinetic Methods.}

According to the reaction rate law, $\mathrm{v}=13.33 \mathrm{~s}^{-1}[\mathrm{DPH}]^{0.906}$, several experiments were conducted to obtain DPH concentration. The selection of the kinetic methods of quantitation was based on the linearity, applicability, sensitivity and reproducibility of these methods. The initial rate, constant rate, and fixed time methods were tried. The first two were discarded, because they presented low linearity, reproducibility, and sensitivity. It was concluded that the fixed time method presents linear correlation for each value of time studied. A group of reaction time values was accurately used and measured $(0$ to $60 \mathrm{~min})$ and their respective linear equations and statistical parameters were obtained (Table 3). According to a Student's t-test (two-tailed) with $n-2$ degrees of freedom and establishing as a null hypothesis $\left(\mathrm{H}_{0}\right)$ the no correlation between the DPH concentration and the $A_{610}$. The results shows that $\mathrm{t}_{\text {calculated }}<\mathrm{t}_{\text {critic }}$, confirming the linear behavior for each time value and refusing the proposed hypothesis. The sensitivity increases with time, but the linear correlation decreases. At 30 min the behavior was more lineal and presented higher sensitivity, but the gain in absorbance units was not significant. However for $t=20$ min the linear and statistical parameters were optimal. This method was selected for the DPH determination since it shows a marked increase in sensitivity.

Table 3. Calibration curves and statistical parameters for different fixed times, DPH concentration ranging between $2.00 \times 10^{-6}$ and $4.00 \times 10^{-5} \mathrm{molL} \mathrm{L}^{-1}$ and $\mathrm{monitoring}$ $A_{610}$.

\begin{tabular}{|c|c|c|c|c|c|}
\hline $\begin{array}{c}t \\
{[\min ]}\end{array}$ & $\mathbf{R}^{2}$ & Typical Error $\left(\mathrm{x}^{-4} 0^{-4}\right)$ & $\begin{array}{c}\mathbf{t} \\
\text { calculated }\end{array}$ & 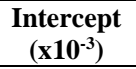 & Slope \\
\hline 0 & 0,9959 & 18,87 & 34,65 & $-1,045$ & 1842,0 \\
\hline 10 & 0,9964 & 58,08 & 37,30 & 13,14 & 6103,2 \\
\hline 15 & 0,9974 & 58,86 & 44,10 & 10,50 & 7312,6 \\
\hline 20 & 0,9984 & 52,92 & 55,06 & 7,626 & 8208,0 \\
\hline 25 & 0,9981 & 58,29 & 50,65 & 11,80 & 8316,3 \\
\hline 30 & 0,9996 & 26,33 & 11,07 & 11,61 & 8683,2 \\
\hline 35 & 0,9978 & 66,66 & 47,68 & 18,86 & 8945,3 \\
\hline 40 & 0,9963 & 88,75 & 36,50 & 15,76 & 9126,4 \\
\hline 50 & 0,9944 & 116,0 & 29,69 & 17,26 & 9706,3 \\
\hline 60 & 0,9900 & 160,0 & 22,28 & 19,80 & 10042,4 \\
\hline
\end{tabular}

$\mathrm{t}_{\text {crit }}(\mathrm{P}=0,05, \mathrm{n}-2) \rightarrow 2,78$ para $\mathrm{N}=6$

\subsection{Calibration Curve and Analytical Parameters using DPH Standard} Solutions.

The analytical parameters were obtained using the selected experimental conditions and DPH standard solutions with 15 independent reagent blanks (without analyte) (Table 4). The accuracy and precision were evaluated with three different values of DPH concentration $\left(4.00 \times 10^{-6} ; 1.00 \times 10^{-5} ; 4.00 \times 10^{-5}\right.$ mol L ${ }^{-1}$ ) through the recovery rate and Student's t-test, respectively. Recovery rates for intraday and interday were obtained (Table 5), with 30 blanks in 5 consecutive days of measurement. This was done with a Student's t-test of 95\% confidence percentage and $n-1$ degrees of freedom. Since the results showed that $\mathrm{t}_{\text {calculated }}<\mathrm{t}_{\text {critic }}$, the differences between observed and expected values are acceptable according to the confidence percentage established as criterion of acceptability. This shows the repeatability and precision in the results. The recoveries were between 100.0 and $101.1 \%$, presenting a satisfactory accuracy for the evaluated kinetic analytical method.
Table 4. Analytical parameters using DPH standards solutions.

\begin{tabular}{|c|c|}
\hline Parameters & Values \\
\hline Linear regression & $\mathrm{A}=7576.3 \mathrm{C}-5.028 \times 10^{-3}$ \\
\hline $\mathrm{R}^{2}$ & 0.9983 \\
\hline $\mathrm{LOD}^{*}\left[\mathrm{~mol} \mathrm{~L}^{-1}\right]$ & $1.27 \times 10^{-6}$ \\
\hline $\mathrm{LOQ}^{*}\left[\mathrm{~mol} \mathrm{~L}^{-1}\right]$ & $3.83 \times 10^{-6}$ \\
\hline Linear Range $\left[\mathrm{mol} \mathrm{L}^{-1}\right]$ & $3.83 \times 10^{-6} \mathrm{a} 1.00 \times 10^{-4}$ \\
\hline$\sigma($ Blanks $)$ & $2.90 \times 10^{-3}$ \\
\hline
\end{tabular}

$* \mathrm{LOD}=3,3 \sigma / \mathrm{m}$ y $\mathrm{LOQ}=10 \sigma / \mathrm{m}$

Table 5. Analysis to assess the precision and accuracy of the proceeding developed for the determination of DPH intraday and interday.

\begin{tabular}{|c|c|c|c|c|c|c|}
\hline $\begin{array}{c}\text { Added } \\
\mathrm{x10}^{-6} \mathrm{molL}^{-1}\end{array}$ & $\begin{array}{c}\text { Found } \\
\times 10^{-6} \mathrm{molL}^{-1}\end{array}$ & $\begin{array}{c}\sigma \\
\mathbf{x} 10^{-8}\end{array}$ & $\begin{array}{l}\mathbf{E S}^{*} \\
\mathbf{x} 10^{-8}\end{array}$ & $\begin{array}{c}\text { Confidence limits } \dagger \\
\times 10^{-8}\end{array}$ & $\mathbf{t}_{\mathrm{cal}}$ & Recovery (\%) \\
\hline \multicolumn{7}{|c|}{ Intra day } \\
\hline 4.00 & 4.02 & 3.96 & 2.29 & 4.83 & 0.22 & 100.4 \\
\hline 10.0 & 10.1 & 4.46 & 2.57 & 5.43 & 0.74 & 100.6 \\
\hline 40.0 & 40.0 & 5.25 & 3.03 & 6.40 & 0.03 & 100.0 \\
\hline \multicolumn{7}{|c|}{ Inter day } \\
\hline 4.00 & 4.01 & 2.10 & 1.21 & 256 & 0.30 & 100.3 \\
\hline 10.0 & 10.1 & 4.89 & 2.82 & 596 & 1.34 & 101.1 \\
\hline 40.0 & 40.0 & 1.38 & 7.99 & 16.9 & 0.01 & 100.0 \\
\hline
\end{tabular}

*Error standard deviation, $\dagger$ confidence limits $\left(\mathrm{mol} \mathrm{L}^{-1}\right)$ with $95 \%$ and $\mathrm{n}-1$ degrees of freedom for intraday and for interday assays $\left(\mathrm{t}_{\text {critic }}=4.3\right)$, and $+\mathrm{t}_{\text {cal }}=\mathrm{t}_{\text {calculated }}$. 


\subsection{Validation and Application.}

The developed procedure was validated in tap water spiked samples and commercial pharmaceutical formulations (Alergyl $®$ injectable).

In the tap water samples the potential interference (organic and inorganic matter) and dissolved gases, were eliminated according to the procedure depicted in Section 2.3.4. Then, samples were fortified with three DPH concentrations $\left(4.00 \times 10^{-6}, 1.00 \times 10^{-5}\right.$ y $\left.4.00 \times 10^{-5}\right)$ according to the procedures of Section 2.3.3. Furthermore, a calibration curve was prepared in tap water in the DPH concentration range of $4.00 \times 10^{-6}-4.00 \times 10^{-5} \mathrm{molL}^{-1}$, using the respective blanks. The analytical parameters obtained are summarized in Table 6 . In order to assess the accuracy, recovery rates were obtained using three analyte concentrations, mentioned above. The measurements for intraday and interday assays were carried out during five consecutive days, using 30 blanks, the recovery rates of the assays were $99.4-100.6 \%$ and $99.7-100.8 \%$, respectively, presenting a satisfactory accuracy for the selected kinetic analytical method, fixed time (Table 7). The effects of possible interference were eliminated through the application of the procedure described in Section 2.3.3.
The application stage was realized in tap water spiked samples according to the respective procedure. For DPH quantitation the linear regression equation obtained in this Section was used. The statistical analysis of the results using Student's t-test and 95\% confidence level showed that there was no significant difference between the real and found concentrations (Table 7).

Table 6. Analytical parameters for the DPH determination using a calibration curve in tap water.

\begin{tabular}{|c|c|}
\hline Parameters & Values \\
\hline Linear regression & $\mathrm{A}=7723.4 \mathrm{C}+7.25 \times 10^{-3}$ \\
\hline $\mathrm{R}^{2}$ & 0.9997 \\
\hline $\mathrm{LOD}^{*}\left[\mathrm{~mol} \mathrm{~L}^{-1}\right]$ & $1.23 \times 10^{-6}$ \\
\hline $\mathrm{LOQ}^{*}\left[\mathrm{~mol} \mathrm{~L}^{-1}\right]$ & $3.73 \times 10^{-6}$ \\
\hline Linear range $\left[\mathrm{mol} \mathrm{L}^{-1}\right]$ & $3.73 \times 10^{-6} \mathrm{a} 1.00 \times 10^{-4}$ \\
\hline$\sigma($ Blanks $)$ & $2.88 \times 10^{-3}$ \\
\hline
\end{tabular}

${ }^{*} \mathrm{LOD}=3,3 \sigma / \mathrm{m}$ y $\mathrm{LOQ}=10 \sigma / \mathrm{m}$

Table 7. Analysis to assess precision and accuracy of the developed method for the determination of DPH intraday and interday in tap water.

\begin{tabular}{|c|c|c|c|c|c|c|}
\hline $\begin{array}{c}\text { Added } \\
\mathrm{x10}^{-6} \mathrm{molL}^{-1} \\
\end{array}$ & $\begin{array}{c}\text { Found } \\
\times 10^{-6} \mathrm{molL}^{-1} \\
\end{array}$ & $\begin{array}{c}\sigma \\
\mathbf{x 1 0 ^ { - 8 }}\end{array}$ & $\begin{array}{l}\text { ES }^{*} \\
\mathbf{x 1 0}^{-8} \\
\end{array}$ & $\begin{array}{c}\begin{array}{c}\text { Confidence limits } \dagger \\
\mathbf{x 1 0}^{-8}\end{array} \\
\end{array}$ & $\mathbf{t}_{\text {cal }}$ : & Recovery $(\%)$ \\
\hline \multicolumn{7}{|c|}{ Intra day } \\
\hline 4.00 & 4.00 & 4.14 & 2.39 & 5.05 & 0.04 & 100.1 \\
\hline 10.0 & 10.1 & 6.28 & 3.63 & 7.66 & 0.59 & 100.6 \\
\hline 40.0 & 39.8 & 10.8 & 6.22 & 13.1 & 1.21 & 99.4 \\
\hline \multicolumn{7}{|c|}{ Inter day } \\
\hline 4.00 & 4.01 & 1.19 & 0.689 & 145 & 0.53 & 100.3 \\
\hline 10.0 & 10.1 & 4.48 & 0.282 & 546 & 0.98 & 100.8 \\
\hline 40.0 & 39.9 & 8.35 & 0.799 & 10.2 & 0.91 & 99.7 \\
\hline
\end{tabular}

*Error standard deviation, $\dagger$ confidence limits $\left(\mathrm{mol} \mathrm{L}^{-1}\right)$ with $95 \%$ and $\mathrm{n}-1$ degrees of freedom for intraday and for interday assays $\left(\mathrm{t}_{\text {critic }}=4.3\right)$, and $\ddagger \mathrm{t}_{\text {cal }}=\mathrm{t}_{\text {calculated }}$.

In the pharmaceutical samples, DPH calibration curve was prepared in this matrix (Alergyl ${ }^{\mathrm{TM}}$ ), over the concentration range of $4.00 \times 10^{-6}-4.00 \times 10^{-5} \mathrm{~mol}$ $\mathrm{L}^{-1}$ using the respective procedure. The analytical parameters obtained are summarized in the Table 8 . In order to assess the accuracy, recovery rates were obtained using three DPH concentrations $\left(4.00 \times 10^{-6}, 2.70 \times 10^{-5}\right.$ y $6.00 \times 10^{-5} \mathrm{~mol}$ $\mathrm{L}^{-1}$ ) prepared with different volumes of Alergyl ${ }^{\mathrm{TM}}$, which were accurately measured according to the procedure of Section 3.3. The measurements for intraday and interday assays were carried out during five consecutive days, using 30 blanks (Table 9), the recovery rates of the assays were $100.3-101.1 \%$ and $100.2-102.3 \%$, respectively, presenting a satisfactory accuracy. The effect of the possible interfering was eliminated through the application of the procedure of Section 2.3.4.
Table 8. Analytical parameters for the DPH determination using a calibration curve in pharmaceutical formulation

\begin{tabular}{|c|c|}
\hline Parameters & Values \\
\hline Linear regression & $\mathrm{A}=8232.6 \mathrm{C}+1.33 \times 10^{-2}$ \\
\hline $\mathrm{R}^{2}$ & 0.9991 \\
\hline $\mathrm{LOD}^{*}\left[\mathrm{~mol} \mathrm{~L}^{-1}\right]$ & $9.65 \times 10^{-7}$ \\
\hline $\mathrm{LOQ}^{*}\left[\mathrm{~mol} \mathrm{~L}^{-1}\right]$ & $2.93 \times 10^{-6}$ \\
\hline Linear Range $\left[\mathrm{mol} \mathrm{L}^{-1}\right]$ & $2.93 \times 10^{-6}-1.00 \times 10^{-4}$ \\
\hline$\sigma($ Blanks) & $2.90 \times 10^{-3}$ \\
\hline
\end{tabular}

*LOD $=3,3 \sigma / \mathrm{m}$ y $\mathrm{LOQ}=10 \sigma / \mathrm{m}$

Table 9. Analysis to assess precision and accuracy of the developed method for the determination of DPH intraday and interday in pharmaceutical formulations

\begin{tabular}{|c|c|c|c|c|c|c|}
\hline $\begin{array}{c}\text { Added } \\
\times 10^{-6} \mathrm{molL}^{-1} \\
\end{array}$ & $\begin{array}{c}\text { Found } \\
\times 10^{-6} \mathrm{molL}^{-1} \\
\end{array}$ & $\begin{array}{c}\sigma \boldsymbol{\sigma} \\
\mathbf{x 1 0 ^ { - 7 }} \\
\end{array}$ & $\begin{array}{l}\text { ES* } \\
\mathbf{x} 10^{-8}\end{array}$ & $\begin{array}{c}\begin{array}{c}\text { Confidence limits } \uparrow \\
\times 10^{-7}\end{array} \\
\end{array}$ & $\mathbf{t}_{\text {cal: }}$ & Recovery $(\%)$ \\
\hline \multicolumn{7}{|c|}{ Intra day } \\
\hline 4.00 & 4.05 & 1.41 & 8.15 & 1.72 & 0.160 & $\begin{array}{ll}101.1 \\
\end{array}$ \\
\hline 27.0 & 27.9 & 5.82 & 33.6 & 3.30 & 0.130 & 100.5 \\
\hline 60.0 & 40.2 & 2.24 & 12.9 & 2.73 & 0.497 & 100.3 \\
\hline \multicolumn{7}{|c|}{ Inter day } \\
\hline 4.00 & 4.01 & 1.64 & 9.48 & 2.00 & 0.027 & 100.2 \\
\hline 27.0 & 27.8 & 5.43 & 31.3 & 13.5 & 3.56 & $\begin{array}{l}102.9 \\
\end{array}$ \\
\hline 60.0 & 60.8 & 2.24 & 12.9 & 2.73 & 2.04 & $\begin{array}{l}101.3 \\
\end{array}$ \\
\hline
\end{tabular}

*Error standard deviation, $\uparrow$ confidence limits $\left(\mathrm{mol} \mathrm{L}^{-1}\right)$ with $95 \%$ and $\mathrm{n}-1$ degrees of freedom for intraday and for interday assays $\left(\mathrm{t}_{\text {critic }}=4.3\right)$, and $\ddagger \mathrm{t}_{\text {cal }}=\mathrm{t}_{\text {calculated }}$.

\section{CONCLUSIONS}

This paper presents an indirect kinetic spectrophotometric method for DPH determination. The method is based on the monitoring of manganate $(610 \mathrm{~nm})$ produced by the permanganate reduction when reacting with DPH in alkaline solutions. Optimal results were obtained by measuring the oxidation kinetic of DPH-KMnO ${ }_{4}$ system using $\mathrm{KMnO}_{4} 1.00 \times 10^{-3} \mathrm{~mol} \mathrm{~L}^{-1}, \mathrm{Na}_{2} \mathrm{SO}_{4} 0.20 \mathrm{~mol} \mathrm{~L}^{-1}$, $\mathrm{NaOH} 0.20 \mathrm{~mol} \mathrm{~L}^{-1}$ and $t=20 \mathrm{~min}$. These optimum values were used in the determination of the stequiometric relation, which was DPH : $\mathrm{KMnO}_{4}=1: 1$. In the kinetic quantitation method selection three methods were used: Initial rate, constant rate, and fixed time. The most suitable method was the fixed time at 20 min, because it presented satisfactory values of analytical parameters $\left(\mathrm{R}^{2}\right.$ and slope). To assay the accuracy and reliability of DPH determination in the proposed samples, several assays were carried out and showed statistically satisfactory results with the recovery rates and the respective Student's t-test, for both types of sample. This method is simple and does not require expensive instruments and complicated extraction steps of the reaction product.

\section{FUNDING STATEMENT}

The authors are grateful to the Fondo Nacional de Investigación en Ciencia y Tecnología (FONDECYT), Project $n^{\circ}$ [1161132], for the financial support. 


\section{REFERENCES}

1. http://www.drugbank.ca/drugs/DB01075.

2. Caddy B., Analyst, vol. 99, n 1182, pp.555-564. 1974.

3. British Pharmacopoeia, Her Majesty's Stationary Office, London, 1988.

4. European Pharmacopoeia, 5th Ed. Main Volume, European Pharmacopoeia Commission, European Directorate for the Quality of Medicines \& Healthcare: Maisonneuve, France, 2005.

5. The United States Pharmacopoeia, United States Pharmacopoeial Convention, Rockville, MD, 2002.

6. H. W. Darwish, F. Metwally, A. EL. Bayoumi, Journal of Nanomaterials and Biostructures, vol. 9, nº 4, pp. 1359-1372, 2014.

7. R. Hajian, E. Kamai, Journal of the Indian Chemical Society, vol. $91, \mathrm{n}^{\circ} 11$, pp. 2133-2141, 2014.

8. B. Devrim, E. Dinc, Acta Poloniae Pharmaceutica, vol. 71, n 5, pp. 721729, 2014.

9. M. El-Didamony, A. Moustafa., Arabian Journal of Chemistry, vol. 3, $n^{\circ} 4$, pp. 265-270 2010.

10. S. Tatar, F. Tuncel, Spectrochimica Acta Part A, vol. 77, n 1 , pp. 324-329, 2010.

11. K. Basavaiah, V. Charan, Indian Journal of Chemical Technology, vol.10, n4, pp. 382-385, 2003.

12. M. Elshahat, M. Badei, J. of Chemical Technology and Biotechnology, vol.54, n², pp.175-181, 1992.

13. G. Santoni, P. Mura, S. Pinzauti, International Journal of Pharmaceutics, vol. $50, n^{\circ} 1$, pp. $75-78,1989$.

14. M. Kishk, Safaa, I. Salama, M. El-Sadek, Journal of liquid chromatography \& related technologies, vol.37, n5, pp.726-747, 2014.

15. R. Dantu Durga, S. Sait, K. Mukkanti, J. of Chromatographic Science, vol.49, nº 4 pp.281-286, 2011.

16. Z. Ge, Y. Luo, X. Zhao, African Journal of Pharmacy and Pharmacology, vol. $5, \mathrm{n}^{\circ} 18$, pp. 2100-2105, 2011

17. D. DiGregorio, J. Sherma, J. of Liquid Chromatography \& Related Technologies, vol. 22, n 10 , pp. 1599-1606, 1999.

18. E. Muller, J. Sherma, J. of Liquid Chromatography \& Related Technologies, vol.22, nº 1, pp.153-159, 1999.

19. I. Caraballo, M. Fernandez, M. Holgado, Drug Development and Industrial Pharmacy, vol.21, n5, pp. 605-613, 1995.

20. S. Raj, S. Kapadia, A. Argekar. Talanta, vol. 46, n¹, pp. 221-225, 1998.

21. Z. Changzhi, C. Xiaoli, T. Shengchen, and J. Kui, Analytical Sciences, vol. 24, nº , pp. 535-538, 2008.

22. I. Reguera, M. Rubio, A. Diaz, Analytical Sciences, vol. 20, n5, pp.799803, 2004.

23. J. Martinez Calatayud, F. J. Blasco Martinez, S. Sagrado Vives. Microchimica Acta, vol.106, n³-6, 319-325, 1992.

24. J. Calatayud, A. Sam Pedro, S. Sarrion, Analyst, vol.115, nº ${ }^{\circ}$, pp.855-858, 1990.

25. M. El Ries, K. Sabry. Journal of Pharmaceutical and Biomedical Analysis, vol. $25, n^{\circ} 1$, pp. 3-7, 2001.

26. S. Khalil. Journal of Pharmaceutical and Biomedical Analysis, vol.21, $n^{\circ} 4$, pp.697-702, 1999.

27. C. Nerin, J. Cacho and A. Garnicao, Journal of Pharmaceutical \& Biomedical Analysis, vol.11, n4-5, pp.411-414, 1993.

28. M. Akl, E. Frag, G. Mohamed, Mohammed S.A. Bashanaini. Int. J. Electrochem. Sci., vol.8, ${ }^{\circ}$ 9, pp.11546-11563, 2013.

29. E. Frag, G. Mohamed, W. El-Sayed. Bioelectrochemistry, vol.82, n`2, pp.79-86, 2011.

30. L. Zhang, Y. Chen, M. Lin, G. Fan, W. Zhao, Y. Wu., Chromatographia, vol.65, n ${ }^{\circ}$ 5-6, pp.305-311, 2007.

31. Y. Donga, X. Chen, Y. Chen, X. Chena, Z. Hu, Journal of Pharmaceutical and Biomedical Analysis vol.39, ${ }^{\circ} 1-2$, pp. 285-289, 2005.

32. A. Marchesini, M.R. Williner, V.E. Mantovani, J.C. Robles, H.C. Goicoechea, Journal of Pharmaceutical and Biomedical Analysis, vol.31, $\mathrm{n}^{\circ} 1$, pp. 39-46.

33. M. Gomez, R. Olsina, L. Martinez, M. Silva, Journal of Pharmaceutical and Biomedical Analysis, vol.30, n³, pp.791-799, 2002.
34. J. Wallace, J. Biggs, and E. Dahl, Analytical Chemistry, vol.38, n 7 , pp.831834,1966

35. L. Chen, X. He, K. Zhou, D. Li, and T. Liu, Latin American Journal of Pharmacy, vol.31, n8, pp.1096-1101, 2012.

36. C. Wang, G. Fan, M. Lin, Y. Chen, and W. Zhao, Journal of Chromatography B-Analytical Technologies in the Biomedical and Life Sciences, vol.854, nº 1-2, pp.48-56, 2007.

37. S. Kumar, D. Rurak and K. Wayne, J. Mass Spectrom., vol.33, $\mathrm{n}^{\circ} 12$, pp.1171-1181, 1998

38. K. Walters-Thompson, W. Mason. Pharmaceutical Research, vol.9, pp. 929 932. 1992.

39. M. Ayad, H. Abdellatef, M. Hosny and Y. Sharaf, European Journal of Chemistry, vol.4, ${ }^{\circ} 1$, pp. $35-43,2013$.

40. M. G. Abdel Wahed, R. El Sheikh, A. A. Gouda, and S. Abou Taleb, Journal of Spectroscopy, vol. 2014, Article ID917234, 12 pages, 2014.

41. A. M. Akhoundi-Khalafi and M. R. Shishehbore, International Journal of Analytical Chemistry, vol. 2015, Article ID 439271, 6 pages, 2015.

42. F. Nacaratte, M. Toral, and C. Soto, J. Chil. Chem. Soc., vol.61, $\mathrm{n}^{\circ} 3$, pp. 3102-3107, 2016.

43. C. Soto, C. Poza, D. Contreras, J. Yáñez, F. Nacaratte, and M. Toral, Journal of Analytical Methods in Chemistry, vol. 2017, Article ID 9812894, 8 pages.

44. Barros D., Statistical design. Chemometrics. First Ed. Elsevier 2006.

45. David Contreras, Claudia Oviedo, Roberto Valenzuela, Juanita Freer, Kimena Rojo, Jaime Rodríguez. J. Chil. Chem. Soc, 54, № 2 (2009), 141.

46. J. Rose, Advanced Physicochemical Experiments, Pitman, London, UK, 1964. 